\title{
Higher Taxa of the Phototrophic Bacteria
}

\author{
NORBERT PFENNIG and HANS G. TRÜPER \\ Institut für Mikrobiologie der GSF, 34 Göttingen, Germany
}

\begin{abstract}
For the families, suborders, and the order of the phototrophic bacteria, legitimate names based on the names of type genera are proposed to replace the illegitimate names used to date. The family names are: Rhodospirillaceae nom. nov., Chromatiaceae Bavendamm 1924, and Chlorobiaceae Copeland 1956; suborder names are: Rhodospirillineae nom. nov. and Chlorobiineae nom. nov.; the order name is Rhodospirillales nom. nov.
\end{abstract}

The familial names Thiorhodaceae Molisch 1907 and Athiorhodaceae Molisch 1907 are illegitimate according to Rule 3 of the International Code of Nomenclature of Bacteria (4). A request to conserve these names (7) was rejected by the Judicial Commission (3). Consequently, to replace Thiorhodaceae we have proposed Chromatiaceae Bavendamm 1924 as the family name for the phototrophic red sulfur bacteria, a name based on Chromatium Perty 1852 , the best known and most studied genus within this group (8). Chromatiaceae is emended to include the genera Chromatium, Thiosarcina, Thiocystis, Thiospirillum, Thiocapsa, Lamprocystis, Amoebobacter, Thiodictyon, Thiopedia, and Ectothiorhodospira.

For the phototrophic nonsulfur bacteria, we herewith propose the familial name Rhodospirillaceae to replace the name Athiorhodaceae Molisch 1907. This new name is based on Rhodospirillum Molisch 1907 as the type genus. The family Rhodospirillaceae further includes the genera Rhodopseudomonas and Rhodomicrobium.

For the family of the phototrophic green sulfur bacteria, the correct name is Chlorobiaceae Copeland 1956 (12). This family in- cludes the genera Chlorobium, Chloropseudomonas, Prosthecochloris, Pelodictyon, and Clathrochloris.

Whereas the two families of the phototrophic red bacteria share many properties, especially as far as the photosynthetic pigments and the fine structure of the cells are concerned, the Chlorobiaceae are distinctly different from them, particularly with respect to the properties mentioned. We therefore think that Chromatiaceae and Rhodospirillaceae should be grouped together in a suborder, Rhodospirillineae subord. nov., and that the Chlorobiaceae should be in a separate suborder, Chlorobiineae subord. nov. Rhodospirillineae will contain the phototrophic bacteria which have bacteriochlorophyll $a$ or $b$ as the major pigment, and the Chlorobiineae will contain those phototrophic bacteria which have bacteriochlorophyll $c$ or $d$ as the major pigment. These suborders are placed in an order which contains the phototrophic (photosynthetic) bacteria: Rhodospirillales ord. nov.

The following illustrates the proposed hierarchy of the higher taxa of the phototrophic bacteria.

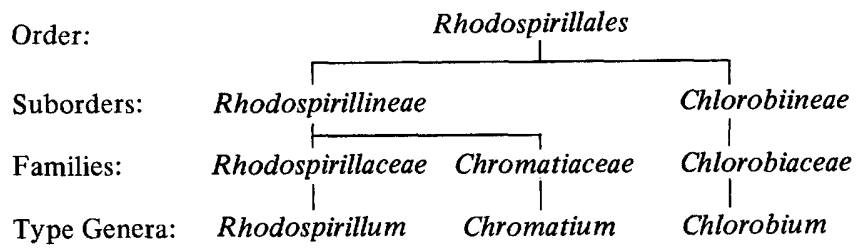




\section{LITERATURE CITED}

1. Bavendamm, W. 1924. Die farblosen und roten Schwefelbakterien des Süss- und Salzwassers. Fischer, Jena.

2. Copeland, H. F. 1956. The classification of lower organisms. Pacific Books, Palo Alto.

3. Editorial Secretary for the Judicial Commission of the International Committee on Systematic Bacteriology. 1971. Minutes of Meeting of the Judicial Commission, Mexico City, Mexico. Int. J. Syst. Bacteriol. 21:(Minute 16).

4. International Code of Nomenclature of Bacteria. 1966. Int. J. Syst. Bact. 16:459-490.

5. Molisch, H. 1907. Die Purpurbakterien nach neuen Untersuchungen. Fischer, Jena.

6. Perty, M. 1852. Zur Kenntnis kleinster Lebensformen. Jent and Reinert, Bern.

7. Pfennig, N., and H. G. Trüper. 1970. Conservation of the family names Thiorhodaceae Molisch
1907, 27 and Athiorhodaceae Molisch 1907, 28 and designation of Chromatium Perty 1852, 174 as the type genus of the Thiorhodaceae and of Rhodospirillum Molisch 1907, 24 as the type genus of the Athiorhodaceae. A recommendation to the Judicial Commission. Int. J. Syst. Bacteriol. 20:31-33.

8. Pfennig, N., and H. G. Trüper. 1971. Conservation of the family name Chromatiaceae Bavendamm 1924 with the type genus Chromatium Perty 1852. Request for an opinion. Int. J. Syst. Bacteriol. 21:15-16.

9. Trüper, H. G., and N. Pfennig. 1971. Family of phototrophic green sulfur bacteria: Chlorobiaceae Copeland, the correct family name; rejection of Chlorobacterium Lauterborn; and the taxonomic situation of the consortium forming species. Request for an opinion. Int. J. Syst. Bacteriol. $21: 8-10$. 